Check for updates

1 Institute for Public Policy Research, London, UK

2 London School of Hygiene and Tropical Medicine, London, UK

3 Midlands Partnership Foundation Trust, Leicester, UK

4 University College London, London, UK

Correspondence to: P Patel parth.patel@ucl.ac.uk Cite this as: BMJ 2020;369:m2282 http://dx.doi.org/10.1136/bmj.m2282 Published: 11 June 2020

\title{
Ethnicity and covid-19
}

\section{Public Health England's review of disparities in covid-19 is a serious missed opportunity Parth Patel, ${ }^{1}$ Lucinda Hiam, ${ }^{2}$ Annabel Sowemimo, ${ }^{3}$ Delan Devakumar, ${ }^{4}$ Martin McKee}

As deaths from covid-19 rose in the UK, it became clear that people with different backgrounds, but united by the label black, Asian, and minority ethnic (BAME), were being affected in numbers far beyond their share of the population. Public Health England (PHE) has undertaken a review documenting the scale of the problem.

Death rates in people known to have covid-19, after taking into account age, sex, deprivation, and region, were twice as high among those of a Bangladeshi background and 10-50\% higher among other ethnic groups compared with white British people. All-cause mortality was almost four times higher in black men and almost three times higher in Asian men than expected for this period based on deaths rates in 2014-18; the figure for white men was 1.7 times higher. Mortality was almost three times higher than expected among black women, 2.4 times higher in Asian women, and 1.6 times in white women. Why? On that, the PHE report is conspicuously lacking.

While the cause of these disparities is probably multifactorial, the silence concerning how structural inequalities may be fuelling this pandemic, and more importantly how these inequalities take root, is notable. Some have suggested possible underlying genetic factors even though data show that all minority ethnic groups are disproportionately affected, many of which have distinctly different genetic ancestry. Some have focused on the role of pre-existing conditions such as diabetes, obesity, and hypertension. Yet the report fails to ask why these conditions are more common in many minority ethnic populations or to explore factors such as material deprivation that might explain them. Others have explored socioeconomic position, occupation, and housing conditions, but most have remained silent on the structural and institutional racism that determines these social factors and also leads to exclusionary health policies that reinforce existing inequalities. All these factors are likely to be contributing to the disparate health outcomes, and it is important to remember their interdependence.

\section{Unanswered questions}

PHE's report brought together a large amount of information but adds little to what was already known. One of the few new contributions was a series of multivariate analyses seeking to explain the risk of death in those aged 20-64, $\geq 65$, and all ages. However, this raised more questions than answers. For example, in univariate analyses of all ages, the risk of death in the main minority ethnic groups was actually lower than for white British, contrary to other analyses. ${ }^{23}$ A single multivariate analysis adjusted for age, sex, region, and deprivation, making it impossible to disentangle the roles played by each factor.

Several commentators, including the leader of the UK Labour Party, Keir Starmer, have criticised the report for failing to investigate the reasons behind the disparities it documents or make recommendations on how to address them. ${ }^{4}$ Given the urgent need for action, this report is a serious missed opportunity.

The government's announcements that "Professor Kevin Fenton, public health director for London will lead the review" and that the "disproportionate impact of covid-19 on black and minority ethnic groups highlights an important focus" were widely welcomed. ${ }^{5}$ Fenton has been a longstanding champion of diversity and anti-racism, and he views community and stakeholder engagement as a critical component of public health. His name is absent from the published report, however, ${ }^{6}$ and ethnicity features only as a small subsection of a much broader report.

PHE said it received evidence from over 1000 organisations and individuals but failed to include their evidence in the final report. The Health Service Journal reports that these organisations and their evidence were included in a previously circulated version but "did not survive contact with Matt Hancock's office."7 The Department of Health and Social Care has denied they were removed from the report.

Following widespread criticism, the government committed to a further review that will make recommendations. Other insights will come from organisations planning to make their own inquiries. The Equality and Human Rights Commission, for example, has announced that it will investigate the "long-standing, structural race inequality" brought into focus by the covid-19 pandemic. ${ }^{8}$

The death of George Floyd in the US has been described as a "symptom of systemic racism." The Black Lives Matter protests sweeping across cities in the US, the UK, and elsewhere point to an anguish not just about police brutality but about the persistent and broad subjugation of marginalised communities by racist societal structures.

All who value equity and justice are pushing for both immediate action and long term change. Yet Kemi Badenoch, the UK's equalities minister, told parliament last week, "We are not taking action which is not warranted by the evidence," ${ }^{10}$ ignoring that the evidence of ethnic inequality and its lethal effects is already plentiful. ${ }^{11}$ Specific policy levers, such as suspending measures that constitute the hostile environment, ${ }^{12}$ could be pulled to reduce the disparities now. 
The inequity described but not explained in PHE's report must not be allowed to persist. The government must act to protect minority ethnic groups before we are hit by this pandemic's imminent second wave.

Competing interests: We have read and understood BMJ policy on declaration of interests and declare the following interests: DD has an honorary position in PHE. AS is a trustee of Medact charity. MM is a member of Independent SAGE.

Provenance and peer review: Commissioned; not externally peer reviewed.

1 Public Health England. Disparities in the risk and outcomes of COVID-19. PHE, 2020.

2 Aldridge R, Lewer D, Katikireddi SV, et al. Black, Asian and minority ethnic groups in England are at increased risk of death from COVID-19: indirect standardisation of NHS mortality data 2020 6 May 2020. https://wellcomeopenresearch.org/articles/5-88.

3 Office for National Statistics. Coronavirus-related deaths by ethnic group, England and Wales methodology 2020. https://www.ons.gov.uk/peoplepopulationandcommunity/birthsdeathsandmarriages/deaths/methodologies/coronavirusrelateddeathsbyethnicgroupenglandandwalesmethod ology.

4 Siddique $\mathrm{H}$, Halliday J. Lack of response to BAME Covid-19 toll risks fuelling tensions, say MPs 2020. Guardian2020 Jun 5. https://www.theguardian.com/politics/2020/jun/05/lack-of-responseto-bame-covid-19-toll-risks-fuelling-tensions-say-mps.

5 Public Health England. Review into factors impacting health outcomes from covid-19. 2020. https://www.gov.uk/government/news/review-into-factors-impacting-health-outcomes-fromcovid-19.

6 Croxford R. Black health expert did not lead BAME Covid report. BBC News 2020 Jun 4. https://www.bbc.com/news/uk-52922046.

7 Moore A. Government censored BAME covid-risk review. Health Serv J 2020.https://www.hsj.co.uk/coronavirus/exclusive-government-censored-bame-covid-risk-review/7027761.article

8 Topping A. UK equality watchdog to launch inquiry into entrenched racism 2020. https://www.theguardian.com/world/2020/jun/05/uk-equality-watchdog-to-launch-inquiry-intoentrenched-racism.

9 Olusoga D. Britain is not America. But we too are disfigured by deep and pervasive racism 2020 https://www.theguardian.com/commentisfree/2020/jun/07/britain-is-not-america-but-we-tooare-disfigured-by-deep-and-pervasive-racism

10 Mohdin A. Too little data for recommendations in covid-19 BAME report, says minister. Guardian 2020 Jun 4. https://www.theguardian.com/politics/2020/jun/04/too-little-data-for-recommendations-in-covid-19-bame-report-says-minister.

11 Marmot M, Allen J, Boyce T, Goldblatt P. Morrison J Health Equity in England: The Marmot Review 10 Years On. 2020. https://www.health.org.uk/publications/reports/the-marmot-review-10-yearson

12 Hiam L, Patel P, Orcutt M, Miller A, Rae M. The move to end the immigration surcharge for NHS workers is welcome, but it does not go far enough. BMJ Opinion. 22 May 2020.

https://blogs.bmj.com/bmj/2020/05/22/the-move-to-end-the-immigration-surcharge-for-nhsworkers-is-welcome-but-it-does-not-go-far-enough/

This article is made freely available for use in accordance with BMJ's website terms and conditions for the duration of the covid-19 pandemic or until otherwise determined by BMJ. You may use, download and print the article for any lawful, non-commercial purpose (including text and data mining) provided that all copyright notices and trade marks are retained. 